\title{
The inflation of human rights: A deconstruction
}

\author{
Jens T. Theilen* \\ Helmut-Schmidt-University, Holstenhofweg 85, 22043 Hamburg, Germany \\ Email: jtheilen@hsu-hh.de
}

\begin{abstract}
There is widespread anxiety about human rights 'inflation': positing too many human rights, it is said, will lead to their devaluation. This article seeks to disentangle the inflation objection from other concerns about rights expansionism and to critically assess it. It considers the scope and implications of the inflation objection by reference to several issues - e.g., which modes of human rights proliferation it covers and which restrictions follow from it - and argues that it is characterized by a formal emptiness since it lacks any specific criteria to indicate which human rights lead to inflation and which do not. The formal emptiness of the inflation objection does not, however, mean that it is politically neutral, for despite its inability to generate closure it does generate a sense of closure by drawing strict boundaries around the corpus of 'proper' human rights. This sense of closure, the article argues, entrenches currently dominant (neo)liberal understandings of human rights while generating suspicion of claims to far-reaching social transformation. In light of this, an alternative to the anti-inflation mindset is suggested: a mindset of wonder, which understands human rights claims outside of dominant understandings not as a threat, but as an opportunity to question the status quo.
\end{abstract}

Keywords: human rights; inflation; neoliberalism; proliferation; utopianism

\section{Introduction: Anxiety about human rights inflation}

Do we have too many human rights? The question keeps resurfacing in debates on human rights. This is by no means self-evident: we might just as well be asking, for example, whether we have too few human rights, ${ }^{1}$ or whether the human rights we do have or those we could have serve the purpose we want them to serve. We might ask whether human rights can lead to meaningful social transformation, ${ }^{2}$ whether they have become primarily tools of governmentality, ${ }^{3}$ and how this relates to whether, how, and which rights claims should be raised. And yet, the question of whether we have too many human rights lurks underneath every debate on the substantive merits of a particular human right or a particular approach to human rights as a whole. For if having too many human rights is undesirable, then this might constitute an argument against making new human rights claims or recognizing certain kinds of claims as human rights - not a decisive argument, necessarily, but at any rate an aspect to consider in making decisions about which rights to claim or recognize.

${ }^{*}$ I would like to thank Janneke Gerards, Stephanie Lagoutte, Sigrid Boysen, and the anonymous reviewers as well as the editors for helpful discussions and comments on the draft article in various stages. Thank you also to all those who provided feedback at the Association of Human Rights Institutes conference in Edinburgh and at the workshop on 'Human Rights Overreach' in Erlangen!

${ }^{1}$ See U. Baxi, The Future of Human Rights (2008), Ch. 4.

${ }^{2} \mathrm{~K}$. McNeilly, Human Rights and Radical Social Transformation: Futurity, Alterity, Power (2018).

${ }^{3}$ B. Sokhi-Bulley, Governing (Through) Rights (2016).

(c) The Author(s), 2021. Published by Cambridge University Press. This is an Open Access article, distributed under the terms of the Creative Commons Attribution licence (http://creativecommons.org/licenses/by/4.0/), which permits unrestricted re-use, distribution, and reproduction in any medium, provided the original work is properly cited. 
Worries that we might have too many rights are often raised by pointing to concerns about the so-called 'inflation' of human rights. ${ }^{4}$ James Nickel has summarized this as the concern that 'positing too many rights' will lead 'to the devaluation of the currency of rights'. ${ }^{5}$ The number of human rights, in other words, is thought to be inversely connected to their value: if the prior rises, the latter may sink. To preserve the value of the human rights project as a whole and prevent 'trivialization', as Anne Peters has put it, ${ }^{6}$ certain claims may not be admitted into the circle of what is rightfully called human rights: 'real' human rights must be distinguished from 'supposed' human rights. ${ }^{7}$

Worries about the inflation of human rights are not new - indeed, they can be traced back at the very least to mid-century responses to the Universal Declaration of Human Rights (UDHR). In one of the foundational texts delineating the inflation objection, Maurice Cranston argued, in 1967, against the inclusion of welfare rights in the UDHR. One of the primary rationales underlying his argument was that:

the effect of a Universal Declaration which is overloaded with affirmations of so-called human rights which are not human rights at all is to push all talk of human rights out of the clear realm of the morally compelling into the twilight world of utopian aspiration. ${ }^{8}$

Over the course of its career, since Cranston and others raised it in reaction to the UDHR, the popularity of the inflation objection has by no means waned. If anything, it may even have risen in response to the increasing popularity of rights language itself. Hurst Hannum, for example, argues that human rights 'are on the verge of becoming a victim of their own success' and that the proliferation of new rights stands in the way of reinvigorating human rights for the twenty-first century. ${ }^{9}$ The number of potential human rights - both new and old - to come under the scrutiny of the inflation objection, then, is immense.

This article sets out to assess the inflation objection, to disentangle it from other objections to human rights expansionism, ${ }^{10}$ and to offer a critique of the way in which it draws boundaries around some human rights at the expense of others by constructing the former as valuable and the latter as threatening. The inflation objection thus shifts the focus away from awkward questions which could be raised about human rights and the boundaries drawn around them. Which human rights should be protected and which rights threaten them? Who decides what counts as a 'real' human right and what doesn't? Who profits from the way in which 'real' human rights are thus constructed?

In particular, I will argue below that it is currently dominant understandings of human rights which are further strengthened by the inflation objection. This is not to imply that there is a singular and unified 'mainstream' understanding, ${ }^{11}$ but merely that the many intersecting power structures at play within human rights discourse combine in such a way as to render certain elements more dominant than others within current institutions. ${ }^{12}$ This may include, for example,

\footnotetext{
${ }^{4}$ On the term, see further infra Section 2.

${ }^{5}$ J. W. Nickel, Making Sense of Human Rights (2007), 96.

${ }^{6}$ A. Peters, Jenseits der Menschenrechte. Die Rechtsstellung des Individuums im Völkerrecht (2014), 396.

${ }^{7}$ M. Cranston, 'Human Rights, Real and Supposed', in D. D. Raphael (ed.), Political Theory and the Rights of Man (1967), cited from P. Hayden (ed.), Philosophy of Human Rights: Readings in Context (1999).

${ }^{8}$ Ibid., at 172 .

${ }^{9}$ H. Hannum, 'Reinvigorating Human Rights for the Twenty-First Century', (2016) 16 Human Rights Law Review 409, 413; see also in more detail H. Hannum, Rescuing Human Rights. A Radically Moderate Approach (2019).

${ }^{10}$ For the distinction, see infra Section 2.

${ }^{11}$ See J. d'Aspremont, 'Martti Koskenniemi, the Mainstream, and Self-Reflectivity', (2016) 29 Leiden Journal of International Law 625, 628.

${ }^{12}$ See infra note 152 for the notion of structural bias which aims to capture this fact.
} 
capitalist, (neo)colonial, heteropatriarchal, and cis-normative elements. ${ }^{13}$ In what follows, my focus will be primarily on those elements within dominant understandings of human rights which reflect and support, or at least do not challenge, commodification and market freedom: these tend to be understood as 'real' human rights, while welfare rights and other rights claims geared at farreaching transformation tend to elicit the inflation objection. Since such an approach draws heavily on a long tradition of liberal human rights theory but also resonates specifically with neoliberal approaches to human rights, I will mostly describe it as '(neo)liberal'. ${ }^{14}$ In sum, then, I will argue that the inflation objection has conservative effects: it makes it more difficult to raise challenges to the (neo)liberal status quo.

My argument will proceed as follows. Section 2 serves as an entry into the topic, clarifying the meaning I assign to the 'inflation objection' compared to related notions such as human rights expansionism or proliferation, explaining why I think it matters, and setting it in relation to different perspectives on human rights in general. I then draw on human rights literature in which the inflation objection is invoked to explore a number of questions which arise as to its scope, implications, and ultimately, its politics. I begin by outlining the scope of the inflation objection, comprising both the creation of 'new' human rights and the interpretation of previously recognized human rights, so as to demonstrate both its potentially immense reach and the dynamic of boundary-setting which comes with it (Section 3) The following section connects this dynamic to the search for that boundary: it asks, in other words, which substantive or procedural restrictions on human rights follow from the inflation objection (Section 4). My argument will be that the inflation objection is characterized by a formal emptiness which means that it does not, and indeed cannot, by itself, hold answers to this question.

The formal emptiness of the inflation objection does not, however, mean that it is devoid of effects: despite its inability to generate closure, it does generate a sense of closure by drawing strict boundaries around the corpus of 'real' human rights. I will call the approach to human rights which this implies a 'mindset of gatekeeping' and explore the way it entrenches dominant,

\footnotetext{
${ }^{13}$ See generally, among many others, H. Charlesworth et al., 'Feminist Approaches to International Law', (1991) 85 American Journal of International Law 613; K. Engle, 'International Human Rights and Feminism: When Discourses Meet', (1992) 13 Michigan Journal of International Law 517; M. Mutua, 'Savages, Victims, and Saviors: The Metaphor of Human Rights', (2001) 42 Harvard International Law Journal 201; B. Rajagopal, International Law from Below. Development, Social Movements and Third World Resistance (2003), Ch. 7; D. Otto, 'Lost in Translation: Re-scripting the Sexed Subjects of International Human Rights Law', in A. Orford (ed.), International Law and its Others (2006); Baxi, supra note 1; D. Otto, 'Queering Gender [Identity] in International Law', (2015) 33 Nordic Journal of Human Rights 299; P. O’Connell, 'On the Human Rights Question', (2018) 40 Human Rights Quarterly 962; R. Kapur, Gender, Alterity and Human Rights (2018); D. A. Gonzalez-Salzberg, 'The Accepted Transsexual and the Absent Transgender: A Queer Reading of the Regulation of Sex/Gender by the European Court of Human Rights', (2014) 29 American University International Law Review 797.

${ }^{14}$ Liberalism and (perhaps even more so) neoliberalism are notoriously slippery terms ('controversial, incoherent and crisisridden': R. Venugopal, 'Neoliberalism as concept', (2015) 44 Economc and Society 165 with further references) but useful, I think, as an approximation to a bundle of ideas that commonly go together (see also S. Hall, 'The neo-liberal revolution', (2011) 25 Cultural Studies 705, 706), e.g., individualism, primacy of the market as the location of human well-being, reliance on law over politics (particularly to constitute and entrench the free market by legally enshrining rights to private property and free trade), and positive outlooks on globalization and commodification. In the context of human rights (as elsewhere), 'neoliberal' is very rarely used as a self-descriptor; liberalism sometimes is, particularly in the Dworkinian tradition (e.g., G. Letsas, A Theory of Interpretation of the European Convention on Human Rights (2007), 5), but on the basis of the elements mentioned above can also be understood more broadly to cover (neo)conservative theories which would hardly self-describe as 'liberal'. Furthermore, while neoliberalism has over time developed particular understandings of human rights (see in detail J. Whyte, The Morals of the Market. Human Rights and the Rise of Neoliberalism (2019), as well as Q. Slobodian, Globalists. The End of Empire and the Birth of Neoliberalism (2018), Ch. 4 on 'xenos rights'), there are significant continuities with the liberal tradition in general (as emphasized, e.g., in the reviews of The Morals of the Market available at legalform.blog, particularly those by Eva Nanopoulos and Paul O'Connell). So, all in all: Building on the approximation of ideas just listed, I will mostly use the deliberately ambiguous '(neo)liberal' to gesture towards these continuities (for common ground with regards to, e.g., the opposition to welfare rights, see in particular infra Section 5.2) while also occasionally drawing on elements which are given particular prominence in accounts of specifically neoliberal human rights (see, in particular, infra Section 2).
} 
(neo)liberal understandings of human rights (Section 5). It does so, I suggest, by virtue of several interrelated effects. For one thing, it distributes authority to decide on human matters in a certain way, positioning rights claims raised by activists or social movements as threatening and statecentred institutions as those responsible for sifting out 'true' human rights (Section 5.1). Secondly, the anti-inflation mindset generates scepticism as to any human rights claims which have significant potential for social transformation, thus strengthening understandings of human rights which do not challenge (neo)liberalism (Section 5.2); and, thirdly, it entrenches the very notion of human rights, thus understood, as particularly fundamental, underlining the superiority of human rights vis-à-vis other forms of morality or social justice (Section 5.3). Differently put, the anti-inflation mindset constructs (neo)liberal understandings of human rights as superior and challenges to the status quo as marginal.

In light of this, my conclusion is that the inflation objection should best be set aside. This does not mean that more human rights are always better or that there cannot be other objections to rights expansionism, but simply that a mindset influenced by the inflation objection is not a helpful way of assessing human rights for those interested in transformative politics. I will close by briefly sketching what I call a 'mindset of wonder' as an alternative to the anti-inflation mindset: we can understand human rights claims outside of dominant understandings not as a threat, but as a chance to wonder at the status quo and reflect on what should be changed in the world (Section 6).

\section{Introducing the inflation objection}

To begin, I would like to dwell briefly on the assumptions undergirding my critique of the inflation objection and the way in which I approach it. First, a few clarifications on terminology and its implications. The term human rights inflation is sometimes used interchangeably with related terms such as human rights expansionism or human rights proliferation, usually with a negative connotation. ${ }^{15}$ My focus here is specifically on human rights inflation, which is the term that most precisely captures the worries I introduced above: that positing too many human rights will lead to a devaluation of human rights as a whole.

Given the connections to (neo)liberal understandings of human rights which I hope to demonstrate in what follows, it is perhaps telling that the inflation objection is so often couched in terms drawn from economics: the 'value' and 'devaluation' of human rights, human rights as 'currency', ${ }^{16}$ and of course the term 'inflation' itself. The debate on human rights inflation could thus be considered a particularly transparent manifestation of what Upendra Baxi has described as 'human rights markets': that increasingly, 'and in mimetic relationship with high economic theory, human rights movements organize themselves in the image of markets' as they produce and reproduce symbolic goods and struggle for resources. ${ }^{17}$ Differently put, there may be significant linkages between social values such as human rights and 'value' in the economic sense. ${ }^{18}$ These linkages also speak to a burgeoning literature that understands neoliberalism not simply as an

\footnotetext{
${ }^{15}$ See J. Griffin, On Human Rights (2008), 93.

${ }^{16}$ E.g., Nickel, supra note 5, at 96; P. Alston, 'Conjuring Up New Human Rights: A Proposal for Quality Control', (1984) 78 American Journal of International Law 607, 614; C. R. Beitz, The Idea of Human Rights (2009), 45; the economic origins of the metaphor usually go unremarked upon, with the notable exception of C. Wellman, The Proliferation of Rights. Moral Progress or Empty Rhetoric? (1999), 177: 'Just as inflation gradually reduces the real value of one's savings because one can now purchase fewer goods and services with the same amount of money, so the rights inflation in political discourse has devalued any and every public appeal to rights'; see also R. Dudai, 'Human Rights in the Populist Era: Mourn then (Re)Organize', (2017) 9 Journal of Human Rights Practice 16, 18.

${ }^{17}$ Baxi, supra note 1 , at 216.

${ }^{18} \mathrm{I}$. Feichtner and G. Gordon, 'Constitutions of Value: Introduction to the Symposium', verfassungsblog, 2 March 2010, available at verfassungsblog.de/constitutions-of-value-introduction-to-the-symposium/; see also the contribution to that symposium by Florian Hoffmann on the value of human rights.
} 
amoral ideology based only on economic rationalities, but rather foregrounds the distinctive moral and legal foundations - including particular understandings of human rights - which neoliberals have built to ensure a competitive market and price stability. ${ }^{19}$

Insofar as I speak of human rights expansionism (or human rights proliferation), I am referring to the more general perception that there are 'many' human rights, and that the corpus of human rights covers an extremely broad range of subject-matters. ${ }^{20}$ In the terminology I adopt, then, human rights inflation is one possible reason to stand opposed to human rights expansionism. This limitation of the scope of my argument is crucial. There are many other objections commonly raised against human rights expansionism, and often intermingled with concerns about inflation: that human rights language is not well suited to respond to certain social problems for example, or that the broad reach of human rights depoliticizes the underlying issues by virtue of increasing legalization and judicialization which come with it. ${ }^{21} \mathrm{I}$ do not attempt to argue against these other objections here - in fact, I agree with many of them. ${ }^{22}$ My aim, rather, is to disentangle the inflation objection from other possible objections to human rights expansionism and consider its implications and effects on its own merits.

One way in which the inflation objection functions differently from other objections to rights proliferation is that, while the latter often share ground with more general critiques of human rights, ${ }^{23}$ the prior implies a positive stance towards the notion of human rights as such. As Charles Beitz has noted, 'the expansion of the scope of international human rights doctrine' can be a cause of concern '[e]ven among those who consider themselves friends of human rights'. ${ }^{24}$ I would go further: concerns about inflation are likely to be prevalent particularly among those sympathetic towards human rights - for worrying about the devaluation of human rights assumes a positive stance towards the concept of human rights as such. ${ }^{25}$

My intention here is not to argue for or against a positive stance towards human rights as such; accordingly, I am not aiming to intervene in the long-standing debate as to whether and how it is desirable to make use of human rights language when aiming for a transformative, left-wing politics. ${ }^{26}$ For present purposes, I will instead take as a given that human rights continue to

\footnotetext{
${ }^{19}$ See, e.g., with different points of emphasis, Whyte, supra note 14, at 8 (and at 175 on inflation); Slobodian, supra note 14, at 9, 17; D. Harvey, Spaces of Global Capitalism. A Theory of Uneven Geographical Development (2019), 51.

${ }^{20}$ Also called rights 'hypertrophy' by E. A. Posner, The Twilight of Human Rights Law (2014), 91; on the politics of the notion of an 'expansion' of rights, see also infra Section 3.

${ }^{21}$ See, e.g., J. Tasioulas, 'Saving Human Rights from Human Rights Law', (2019) 52 Vanderbilt Journal of Transnational Law 1167; D. Clément, 'Human Rights or Social Justice? The Problem of Rights Inflation', (2018) 22 International Journal of Human Rights 155; see also Peters, supra note 6, at 395.

${ }^{22}$ For a summary of some possible objections see, e.g., D. Kennedy, The Dark Sides of Virtue. Reassessing International Humanitarianism (2004). As I revise this article, Black Lives Matter protests against systemic racism and policy brutality are erupting around the world in reaction to police killings of Breonna Taylor, George Floyd and others, often including demands to abolish the police and prisons. In such a historical moment, when abolition has become less of a fringe topic, it becomes particularly relevant to note what is coming to be known as the objection of human rights (coercive) 'overreach', i.e., objection to the continuing expansion of human rights in such a way as to require and rely on coercive measures taken by the penal state. The primary concern here is not that this expansion 'devalues' human rights (although that concern, too, is sometimes present in writings on the topic), but rather with the underlying assumption that carceral solutions are necessary rather than harmful. See generally A. Y. Davis, Are Prisons Obsolete? (2003) and in the context of human rights law, e.g., K. Engle, 'Anti-Impunity and the Turn to Criminal Law in Human Rights', (2015) 100 Cornell Law Review 1069; N. Mavronicola, 'Taking Life and Liberty Seriously: Reconsidering Criminal Liability Under Article 2 of the ECHR', (2017) 80 Modern Law Review 1026.

${ }^{23}$ E.g., a critique of depoliticization through rights discourse becomes all the more relevant in light of rights proliferation.

${ }^{24}$ Beitz, supra note 16, at 45; see also Posner, supra note 20, at 92; contrast Tasioulas, supra note 21, at 1194.

${ }^{25}$ See further infra Section 5.3 for the hierarchization this involves vis-à-vis other normative frames.

${ }^{26}$ For some important recent contributions to this debate see B. Golder, 'Beyond Redemption? Problematising the Critique of Human Rights in Contemporary International Legal Thought', (2014) 2 London Review of International Law 77; Kapur, supra note 13.
} 
be a highly relevant language (of governmentality, but also of resistance) in practice ${ }^{27}$ - an 'undeniably empirical element' of the world, as Florian Hoffmann has put it. ${ }^{28}$ My assumption is therefore that the way in which human rights discourse is shaped - including, inter alia, by the inflation objection - holds practical relevance and is therefore worth engaging with. However, this is not to say that my argument in what follows is politically neutral vis-à-vis the notion of human rights: to the contrary, my goal is to show how the inflation objection focuses on an abstract notion of the 'value' of human rights rather than the specific privileges, power constellations, and struggles which underlie them. ${ }^{29}$ Accordingly, my suggestion would be that those of us invested in transformative politics and challenges to the (neo)liberal hegemony should be wary of this kind of 'devotion' to the notion of human rights. ${ }^{30}$

I will consider the inflation objection primarily through an analysis of scholarly literature on human rights, since it is in that context that it is most often voiced. ${ }^{31}$ To give a counter-example: courts or quasi-judicial bodies, to my knowledge, barely ever refer explicitly to concerns about inflation in their processes of justification. This is hardly surprising since they usually wish to present themselves as focused on legal interpretation (is a certain law or practice a violation of the human rights document at issue according to legal standards?) rather than broader political considerations (will a certain interpretation contribute to a devaluation of human rights as a whole and does this matter?). ${ }^{32}$

I do not think, however, that the relevance of the inflation objection is consigned to scholarly works. To stay with the example of courts, they may not explicate the inflation objection in their processes of justification, but it may well influence judges during the processes of interpretation leading up to their judgments. ${ }^{33}$ I will elaborate further on this idea of 'influence' on decisions (whether by courts or other actors) below, by reference to the inflation objection as a mindset from within which human rights issues may be approached. ${ }^{34}$ At a more general level, my assumption is simply that conceptualizations of human rights developed, inter alia, in scholarly or theoretical works, are not separable from the power relations which structure the everyday practice of human rights. Through the lens of ideology critique, Susan Marks has succinctly captured this assumption by arguing that 'analyses affect outcomes, knowledge is bound up with power' ${ }^{35}$ If we understand neoliberalism as an economic rationality that is not as such amoral but rather consciously and deliberately buttressed by the 'power of ideas ${ }^{36}$ to ensure the smooth functioning

\footnotetext{
${ }^{27}$ See, e.g., O'Connell, supra note 13 , at 963 .

${ }^{28}$ F. F. Hoffmann, “Shooting into the Dark”: Toward a Pragmatic Theory of Human Rights (Activism)', (2006) 41 Texas International Law Journal 403, 405.

${ }^{29}$ There is, perhaps, a rough analogy to be drawn here with the way in which the fragmentation debate has been said to focus on the abstract notion of 'coherence' while masking underlying concerns about judicial competence: see M. Koskenniemi and P. Leino, 'Fragmentation of International Law? Postmodern Anxieties', (2002) 15 Leiden Journal of International Law 553. A related but distinct line of argument focuses on 'the cost of human rights to international law as a whole': I. Wuerth, 'International Law in the Post-Human Rights Era', (2017) 96 Texas Law Review 279, 284.

${ }^{30}$ See K. McCall-Smith, 'The Proliferation of Human Rights: Between Devotion and Calculation', in J. Wouters, et al. (eds.), Can We Still Afford Human Rights? Critical Reflections on Universality, Costs and Proliferation (2020), 114, building on David Kennedy.

${ }^{31}$ However, different actors (e.g., social movements as opposed to state or inter-state institutions) play very different roles in these academic accounts: see especially infra Section 5.1 .

${ }^{32}$ As with other arguments that are considered extra-legal: see generally, e.g., K. Dzehtsiarou, European Consensus and the Legitimacy of the European Court of Human Rights (2015), Ch. 6; R. Mann, 'Non-ideal Theory of Constitutional Adjudication', (2018) 7 Global Constitutionalism 14.

${ }^{33}$ For the distinction see R. A. Wasserstrom, The Judicial Decision. Toward a Theory of Legal Justification (1961), 27; similarly N. Luhmann, Recht und Automation in der öffentlichen Verwaltung. Eine verwaltungswissenschaftliche Untersuchung (1966), 51; processes of interpretation are generally confidential.

${ }^{34}$ See infra Section 5.1 .

${ }^{35}$ S. Marks, The Riddle of All Constitutions. International Law, Democracy, and the Critique of Ideology (2000), 5.

${ }^{36}$ Slobodian, supra note 14 , at 124 .
} 
of the market, as mentioned above, then a critique of neoliberal ideology becomes all the more important.

In structuralist terms, one might say that my aim is to consider the inflation objection as one of many elements which form part of the 'underlying world of beliefs that controls our institutional practices' insofar as human rights are concerned. ${ }^{37}$ My motivation for discussing the inflation objection stems from the sense that it paints a picture of human rights which I am uncomfortable with, one which locks in certain human rights as worth protecting from devaluation or trivialization while simultaneously drawing a hard line around them and raising scepticism about other (claims to) human rights. It constitutes, in other words, one part of a 'world of beliefs' which I think is worth making explicit and challenging.

Of course, to speak of 'the' inflation objection belies the many different ways in which it has been and can be raised, even if we restrict our purview to the literature on human rights. ${ }^{38}$ Human rights themselves are multidimensional, forming part of political, moral and legal discourses; ${ }^{39}$ accordingly, theories of human rights have been developed in many different disciplines and with very different points of emphasis. ${ }^{40} \mathrm{I}$ do not think that these distinctions carry particular weight in the present context since the basic contours of the inflation objection and (neo)liberal ideology, as just described, cut across academic disciplines. It is worth noting at the outset, however, that the kind of boundary-drawing which I take the inflation objection to effect reinforces ways of thinking already present with particular force in legalized human rights discourse and law more generally: the idea that there is a clear boundary between human rights violations and permissible state conduct, ${ }^{41}$ and ultimately between law and politics. ${ }^{42}$ It comes as no surprise that those who invoke the inflation objection also argue that 'the status of human rights as law needs to be protected and that the distinction between legal obligations and other obligations of a moral or political nature needs to be maintained'. ${ }^{43}$ The policing of law's boundaries, then, will haunt the discussion that follows even as my primary focus is on the boundaries of human rights more generally. ${ }^{44}$ That law should play such a role is perhaps unsurprising, given the central role it plays within neoliberalism as a vehicle for articulating political claims. ${ }^{45}$

Finally, a word on method. I have labelled the analysis which follows a 'deconstruction', a label I use somewhat hesitantly given the manifold different expectations which it may invoke, some of which I will certainly not live up to here (as the mere mention of 'method' makes clear). I nonetheless take the label to be useful, primarily for two reasons. First, it has been taken up in some international legal scholarship in a way which draws attention to the structuralist elements of analysis mentioned above. ${ }^{46}$ Second, and more importantly, it invokes a sense of the dynamics involved in certain forms of argument which very accurately captures my experience while trying

\footnotetext{
${ }^{37}$ M. Koskenniemi, 'What is Critical Research in International Law? Celebrating Structuralism', (2016) 29 Leiden Journal of International Law 727, 733.

${ }^{38}$ E.g., human rights theory of various kinds as well as arguments against specific human rights; even those who argue in favour of 'new' human rights claims sometimes measure them, albeit on their account successfully, against a bar that is influenced by worries about inflation: See, e.g., R. Andorno, 'The Relevance of Human Rights for Dealing with the Challenges Posed by Genetics', in A. von Arnauld et al. (eds.), Cambridge Handbook of New Human Rights. Recognition, Novelty, Rhetoric (2020), 336-8.

${ }^{39}$ A. von Arnauld and J. T. Theilen, 'Rhetoric of Rights: A Topical Perspective on the Functions of Claiming a "Human Right to ..."', in von Arnauld et al., ibid., at 45.

${ }^{40}$ See, e.g., for controversies about the role of law in human rights theory A. Sen, 'Elements of a Theory of Human Rights', (2004) 32 Philosophy \& Public Affairs 315, 319; A. Buchanan, The Heart of Human Rights (2013), 3.

${ }^{41}$ See E. Brems, 'Human Rights: Minimum and Maximum Perspectives', (2009) 9 Human Rights Law Review $349,350$.

${ }^{42}$ M. Koskenniemi, From Apology to Utopia: The Structure of International Legal Argument (2005), 16.

${ }^{43}$ Hannum, supra note 9 (2016), at 411.

${ }^{44}$ For a discussion of the boundaries of law, see also infra Section 6.

${ }^{45}$ Harvey, supra note 19, at 51; see generally H. Brabazon (ed.), Neoliberal Legality. Understanding the Role of Law in the Neoliberal Project (2017).

${ }^{46}$ Koskenniemi, supra note 42,6 .
} 
to make sense of the literature invoking the inflation objection as it oscillates between different terms and assumptions. ${ }^{47}$ If, as I will argue, the inflation objection constructs some categories (of human rights, or human rights themselves) as superior and others as marginal in a way which has conservative effects, then there is hope in the fact that these hierarchizations are not static but rather engaged 'in a more unsettled and dynamic tacit relation'. ${ }^{4}$

\section{The scope of the inflation objection: Interpretation and (over)expansion}

Having introduced the inflation objection in broad strokes, this section provides an overview of how its scope is delineated by those who invoke it. Differently put: how does the proliferation of human rights to which the inflation objection responds come about? By introducing the inflation objection in this way, my aim is both to provide a sense of its potentially wide-ranging implications and to demonstrate how - because of the tensions involved in delineating its scope - the inflation objection is drawn towards the kind of boundary-drawing which I mentioned above.

The traditional focus of the inflation objection, besides a general concern about welfare rights, lies on issues which have been newly (pro)claimed in the form of a 'human right to ...'. Writing in 1984, Philip Alston mentioned numerous examples of 'new' human rights claims, ranging from the right to tourism and the right to disarmament over the right to sleep, the right not to be killed in a war, the right of access to challenging work requiring creativity, the right to self-education and education with others, to the right to coexistence with nature, ${ }^{49}$ as well as those rights already recognized in some form by United Nations organs such as the right to development, the right to peace, the right to a clean environment and the right to popular participation. ${ }^{50}$

Over two decades later, many of these 'human rights to ...' continue to raise questions about human rights inflation. ${ }^{51}$ In addition, novel formulations of human rights have only increased in recent years. To name just a few examples from the copious literature and practice, one might consider the human right to internet access, ${ }^{52}$ a 'right to be loved', ${ }^{53}$ peasant rights and the human right to land, ${ }^{54}$ the right to read, ${ }^{55}$ and the human rights of older persons. ${ }^{56}$ Furthermore, some rights claims seek to expand the very notion of 'human' rights by declaring animal rights ${ }^{57}$ or rights of nature. ${ }^{58}$

All these examples illustrate that there is ample room for concern about the proliferation of newly formulated 'human rights to ...' from the perspective of the inflation objection - but this is not the only mode of proliferation which it takes issue with. The substance of human rights,

\footnotetext{
${ }^{47}$ What could be described as its 'self-transgression', or the movement that threatens to collapse the system: see Spivak's 'Translator's Preface', in J. Derrida, Of Grammatology (1976), lxxv.

${ }^{48}$ E. K. Sedgwick, Epistemology of the Closet (2008), 9-10; in the context of international law see M. Koskenniemi, 'Letter to the Editors of the Symposium', (1999) 93 American Journal of International Law 351, 355.

${ }^{49}$ Alston, supra note 16 , at $607,610-11$.

${ }^{50}$ Ibid., at $612-13$.

${ }^{51}$ E.g., S. Bouwhuis, 'Revisiting Philip Alston's Human Rights and Quality Control', (2016) European Human Rights Law Review 475; Hannum, supra note 9 (2016), at 432-6.

${ }^{52} \mathrm{~B}$. Çall, 'The Case for the Right to Meaningful Access to the Internet as a Human Right in International Law', in von Arnauld et al., supra note 38 .

${ }^{53}$ S. M. Liao, The Right to Be Loved (2015).

${ }^{54}$ C. Heri, 'Justifying New Rights: Affectedness, Vulnerability, and the Rights of Peasants', (2020) 21 German Law Journal 702.

${ }^{55}$ L. Shaver, 'The Right to Read', (2015) 54 Columbia Journal of Transnational Law 1.

${ }^{56}$ F. Mégret, 'The Human Rights of Older Persons: A Growing Challenge', (2011) 11 Human Rights Law Review 37.

${ }^{57}$ See, e.g., A. D’Amato and S. K. Chopra, 'Whales: Their Emerging Right to Life', (1991) 85 American Journal of International Law 21; M. C. Nussbaum, Frontiers of Justice. Disability, Nationality, Species Membership (2006); A. Peters, 'Liberté, Égalité, Animalité: Human-Animal Comparisons in Law', (2016) 5 Transnational Environmental Law 25.

${ }^{58}$ S. Borràs, 'New Transitions from Human Rights to the Environment to the Rights of Nature', (2016) 5 Transnational Environmental Law 113.
} 
after all, can be debated without (pro)claiming a new 'human right to ...': one can rely on the right to freedom of expression rather than speaking of a 'right to insult $;{ }^{59}$ one can discuss whether night flights which cause a certain level of noise for residents near an airport should be prohibited by referring to the right to respect for private life or the right to health rather than a 'right to sleep well'; ${ }^{60}$ and the rights of various disadvantaged groups can be framed as applications of general human rights rather than naming them specifically as women's rights, gay rights, trans rights, the rights of persons with disabilities, and the like. ${ }^{61}$ Particularly when (quasi-)judicial pronouncements on matters of human rights are at issue, it is likely that courts and other supervisory bodies will refer back to more general rights clearly articulated in the positive law they are interpreting, rather than framing their conclusions as a free-standing 'human right to ...'.62

Worries about inflation are liable to be more prominent when a flashy 'human right to ...' is (pro)claimed - understandably so, to some extent, since it may come to constitute a discursive hub which prompts jurisgenesis and contributes to yet further proliferation of human rights. ${ }^{63}$ (More cynically, one might also say: those who disapprove of a certain right and wish to argue against it on grounds of inflation are themselves more likely to frame it as a 'human right to ...' so as to make it seem more boisterous than it otherwise would.) But if the concern is that we will lose sight of the 'distinctive significance of human rights' if they are inflated in such a way as to cover all of morality or any issue pertaining to social justice, ${ }^{64}$ then those cases in which there is no explicit reliance on a newly phrased 'human right to ...' seem similarly if not equally relevant.

Concerns about inflation thus encompass not only enumerated 'human rights to ...', the number of which would in any case depend on the level of generality they are phrased at, ${ }^{65}$ but are rather directed at the 'huge scope of human activity' which human rights cover in substance. ${ }^{66}$ Stephen Bouwhuis deems this 'a more modern tension in the creation of human rights, namely an expansion of their ambit through their elaboration'. ${ }^{67}$ Thus, elaboration or interpretation of accepted rights comes within the scope of the inflation objection: rights might be interpreted expansively, for example in response to societal, scientific or technological developments, ${ }^{68}$ and it is not only their number (however defined) but also their content which may contribute to human rights inflation. ${ }^{69}$

Much depends here on how one approaches the issue of interpretation of human rights and, consequently, what kind of connections are acknowledged between different (expressions of) human rights. For example, Alston treated the various 'human rights to ...' which he considered as a form of creation ex nihilo: he described them as having been 'literally conjured up, in the dictionary sense of being "brought into existence as if by magic". ${ }^{70}$ Yet this over-simplifies

\footnotetext{
${ }^{59}$ A. Clooney and P. Webb, 'The Right to Insult in International Law', (2017) 48 Columbia Human Rights Law Review 1.

${ }^{60}$ Letsas, supra note 14 , at 126.

${ }^{61}$ One instance in which this connection to general human rights law is strongly emphasized, even as group-specific rights are claimed, may be found in the Yogyakarta Principles on the application of international human rights law in relation to sexual orientation and gender identity. However, there are many more complicated threads between the general and the specific to be unravelled in such contexts; see, e.g., F. Mégret, 'The Disabilities Convention: Human Rights of Persons with Disabilities or Disability Rights?', (2008) 30 Human Rights Quarterly 494.

${ }^{62}$ See, e.g., J. T. Theilen, 'Pre-existing Rights and Future Articulations: Temporal Rhetoric in the Struggle for Trans Rights', in von Arnauld et al., supra note 38, at 212.

${ }^{63}$ On 'human rights to ...' as discursive hubs, see in more detail von Arnauld and Theilen, supra note 39 , at 47.

${ }^{64}$ Tasioulas, supra note 21 , at 1191-2.

${ }^{65}$ Griffin, supra note 15 , at 93 .

${ }^{66}$ Posner, supra note 20 , at 151.

${ }^{67}$ Bouwhuis, supra note 51, at 481; see also S. P. Marks, 'Normative Expansion of the Right to Health and the Proliferation of Human Rights', (2016) 49 George Washington International Law Review 101, 105; Clément, supra note 21, at 155-6.

${ }^{68}$ See McCall-Smith, supra note 30, at 133, 141.

${ }^{69}$ Wellman, supra note 16 , at 169

${ }^{70}$ Alston, supra note 16, at 607, citing the Concise Oxford Dictionary; contrast B. Lewis, 'Quality Control for New Rights in International Human Rights Law: A Case Study of the Right to a Good Environment', (2015) 33 Australian Yearbook of
} 
matters: even when 'human rights to ...' are newly (pro)claimed, they are rarely disconnected entirely from more established rights. Those who argue for a free-standing human right to water, for example, acknowledge its connections to other human rights such as the right to life, the right to health, and the right to an adequate standard of living ${ }^{71}$ - and indeed rely on argumentative links to these rights even as they frame the human right to water as its own topos. Of course, such argumentative links are bound to remain controversial; but there need not be any magic involved.

Conversely, if an issue is brought within the ambit of human rights through their elaboration or interpretation, i.e., no newly phrased 'human right to ...' is (pro)claimed, then the argumentative links to established human rights are more readily apparent. On an interpretivist account, indeed, one might even claim that in interpreting human rights, a court is not 'expanding or inflating' their scope, but 'merely discovers what these human rights always meant to protect'. ${ }^{72}$ Such an account, however, glosses over the political aspect involved in specifying the content of human rights: ${ }^{73}$ the metaphor of discovery makes the interpretive process seem predetermined whereas it is, in fact, never devoid of a decisional aspect. ${ }^{74}$

Creation, then, involves elements of elaboration, while elaboration involves elements of creation; ${ }^{75}$ Corina Heri has very aptly captured the resulting ambiguities by speaking of the development of 'new-ish' rights, given that there is both a creative element in positing any particular rights claim and an area of overlap with previous rights iterations. ${ }^{76}$ In light of this, it makes perfect sense to give the inflation objection a broad scope, and to not restrict it to any one mode of human rights proliferation.

Still, there remains a tension. So as to understand the elaboration or interpretation of the content of human rights as subject to the inflation objection, it must be construed - as indeed it explicitly is in the citation by Bouwhuis mentioned above - as an 'expansion'. ${ }^{77}$ Kasey McCall-Smith has made this connection particularly clear by juxtaposing evolutive interpretation of human rights with the notions of both 'expansion' and 'inflation'. ${ }^{78}$ Others even speak of 'overexpansive interpretations' ${ }^{79}$ But once elaboration becomes (over)expansion, it becomes difficult to demarcate any 'pre-expansion' content of human rights which the inflation objection serves to protect.

Differently put, it becomes difficult to remove the implementation of established rights from the scope of the inflation objection; ${ }^{80}$ as Allen Buchanan has noted, the distinction 'between legal rights and administrative directives designed to give them effect' is 'conspicuously absent' in human rights conventions. ${ }^{81}$ The difficulty of drawing a line between 'mere' implementation and potentially expansive interpretation is not specific to debates about inflation, of course.

International Law 55, 55, who mentions concerns about inflation where 'so-called new rights are in fact merely reiterations of existing rights'.

${ }^{71}$ E.g., T. S. Bulto, 'The Emergence of the Human Right to Water in International Human Rights Law: Invention or Discovery?', (2011) 12 Melbourne Journal of International Law 1, 5.

${ }^{72}$ G. Letsas, 'The ECHR as a Living Instrument: Its Meaning and Legitimacy', in A. Føllesdal et al. (eds.), Constituting Europe. The European Court of Human Rights in a National, European and Global Context (2013), 125 (emphasis in original).

${ }^{73} \mathrm{~B}$. Golder, 'On the Varieties of Universalism in Human Rights Discourse', in P. Agha (ed.), Human Rights Between Law and Politics: The Margin of Appreciation in Post-National Contexts (2017), 49.

${ }^{74}$ See generally, e.g., D. Kennedy, 'A Semiotics of Critique', (2001) 22 Cardozo Law Review 1147, 1163.

${ }^{75}$ See von Arnauld and Theilen, supra note 39, at 36-9 for an attempt to describe the resulting dynamics through the topical school of rhetorics, especially the elements of habituality and potentiality.

${ }^{76}$ Heri, supra note 54 , at 712 .

${ }^{77}$ Supra, note 67.

${ }^{78} \mathrm{McC}$ Call-Smith, supra note 30 , at 133 ; in her terminology, 'expansion' denotes a positive perspective on new interpretations, while 'inflation' signals criticism: but they are both instances of human rights 'evolution'.

${ }^{79}$ Buchanan, supra note 40 , at 286 .

${ }^{80}$ For a rare attempt to explicitly undertake this distinction see Marks, supra note 67 , at 134 and throughout.

${ }^{81}$ Buchanan, supra note 40 , at 291 ; for an argument attempting to make a clear distinction between human rights and their implementation so as to restrict prioritization of some issues over others to the latter see A. Quintavalla and K. Heine, 'Priorities and Human Rights', (2019) 23 International Journal of Human Rights 679. 
But since part of the motivation for the inflation objection is to prioritize the effectiveness of a certain group of (say, relatively established) rights over the assertion of other (say, newer) rights, ${ }^{82}$ it seems somewhat counter-intuitive to submit the implementation of the prior to an inflationbased scrutiny. While any elaboration or interpretation of human rights can come within the scope of the inflation objection, then, it needs to be geared only at a subset of cases which are read as 'expansion' so as to retain a field of 'non-expansion' for those rights interpretations which it seeks to protect from inflation.

To summarize, then, the scope of the inflation is simultaneously vast and constrained: vast, in that any 'human right to ...' or any elaboration or interpretation of a human right can, in theory, be met by the inflation objection, but simultaneously constrained, in that the internal logic of the inflation objection demands a certain set of human rights or human rights interpretations to prioritize over others and thus be excluded from its own scope. A boundary of some sort therefore needs to be set: one might say that this is necessary to prevent an inflation of concerns about inflation. Because of the ambiguities involved in capturing rights claims as either creation or elaboration, and the resulting difficulty of demarcation which substantive elements are consider an 'expansion' of rights, however, this boundary remains highly unstable.

\section{The formal emptiness of the inflation objection}

The question then arises, of course, how this boundary should be drawn: which restrictions on human rights follow from the inflation objection? The basic impetus of the inflation objection is fairly clear: if the worry is that the increasing expansion of human rights will lead to their devaluation or trivialization by 'eroding the legitimacy of a defensible core of rights', as Michael Ignatieff has put it, ${ }^{83}$ then the content of human rights will have to be in some way limited. But how are these limitations ascertained?

Different authors writing on inflation have, unsurprisingly, proposed different responses. Ignatieff's own response is to define the 'defensible core' as those rights which are 'strictly necessary to the enjoyment of any life whatsoever' ${ }^{84}$ Others have proposed different but similar tests: for example, Maurice Cranston relied on the notions of universality, practicability, and paramount importance. ${ }^{85}$ More recently, John Tasioulas seeks to restrict human rights law to those rights which give appropriate expression and effect to an underlying morality of universal rights, characterized in particular by the fact that they - unlike, e.g., interests or values, on Tasioulas's account - are associated with obligations. ${ }^{86}$

However, as Alston has noted in response to Cranston, 'philosophers can always have a field day debating the elements to be included in such a list of substantive criteria for determining whether a given claim qualifies as a human right', yet in the practice of international organizations, the same exercise 'becomes infinitely more difficult'. ${ }^{87}$ Substantive criteria 'imply a degree of rationality and objectivity in the selection of rights that simply does not and could not characterize the approach of a body such as the United Nations'; human rights remain, after all, 'a quintessentially political issue'. ${ }^{88}$ Or, as Makau wa Mutua has summarized it, while a 'diverse and eclectic assortment of individuals and entities now invoke human rights norms', this 'universal reliance on the language of human rights' has failed 'to create agreement on the scope, content, and philosophical bases of the human rights corpus' ${ }^{89}$ Alston's response to this issue, while simultaneously seeking

\footnotetext{
${ }^{82}$ See A. Gutmann, 'Introduction', in M. Ignatieff, Human Rights as Politics and Idolatry (2001), x.

${ }^{83}$ Ignatieff, ibid., at 90 .

${ }^{84}$ Ibid.

${ }^{85}$ Cranston, supra note 7 , at 170 .

${ }^{86}$ Tasioulas, supra note 21 , at 1181 .

${ }^{87}$ Alston, supra note 16 , at 616 .

${ }^{88}$ Ibid., at 617 .

${ }^{89}$ M. w. Mutua, 'The Ideology of Human Rights', (1996) 36 Virginia Journal of International Law 589, 590.
} 
to prevent inflation of human rights, is to focus on procedural criteria as 'an indirect means to achieve many of the same objectives': ${ }^{90}$ he relies on Richard Bilder's claim that an international human right exists if the United Nations General Assembly says it does. ${ }^{91}$

We thus reach the well-known tension between substance and process, a tension which demonstrates the difficulty in specifying any kind of principled standards for preventing human rights inflation. Alston is quite right, I think, to foreground the political aspect of human rights in response to philosophical over-confidence in distinguishing 'real' from 'supposed' rights in the way which Cranston envisages. ${ }^{92}$ But the turn to procedures carries its own problems. For one thing, much depends on which body is considered the competent authority. The much-discussed fragmentation of international law pertains to human rights not only by virtue of their relationship to 'general' international law, ${ }^{93}$ but also insofar as human rights norms and institutions have become increasingly diverse within themselves: there is an increasing number of legal texts and institutions that focus on human rights, and different fora may provide different answers as to whether a certain issue is (covered by) a human right. ${ }^{94}$

For those concerned about human rights inflation, such fragmentation further exacerbates the problem: the multiplication of available fora gives applicants and social movements increased chances of their claims being recognized in at least some of those fora, and hence potentially contributes to the devaluation of human rights by expanding their reach in some contexts at least. ${ }^{95}$ In other words, concerns about human rights inflation carry a unifying undercurrent which makes the fragmentation of international human rights law seem problematic. Faced with the fact that such fragmentation does exist, it becomes ever more difficult to establish any kind of procedure to definitively establish which human rights are recognized and which are not. At the very least, one would have to rely on some kind of extra-procedural standards to establish which procedures are deemed relevant.

The fragmentation of international law is, in this respect at least, only a particularly tangible expression of a more general issue, for any reliance on process ends up relying on substance in some way, if only to establish the relevant procedures and why they should matter, or the standards which should be applied within these procedures. ${ }^{96}$ Furthermore, a purely procedural approach would not sufficiently capture the moral significance commonly assigned to human rights, so that it can in turn always be criticized from a substantive viewpoint. In that vein,

\footnotetext{
${ }^{90}$ Alston, supra note 16 , at 617.

${ }^{91}$ R. B. Bilder, 'Rethinking International Human Rights: Some Basic Questions', (1969) Wisconsin Law Review $171,173$.

${ }^{92}$ As the title of his article ('Human Rights, Real and Supposed') makes clear, see supra note 7; see also, e.g., Wellman, supra note 16, at 178, distinguishing between 'real' and 'illusory' moral rights (partly in reference to Cranston, e.g., at 3), and recently P. Pinto de Albuquerque, 'Plaidoyer for the European Court of Human Rights', (2018) European Human Rights Law Review 119,120 , connecting critiques of the European Court of Human Rights to the conflict between 'genuine' and 'fake' human rights. This over-confidence also applies in the specific context of human rights law: on the 'familiar hubris' of finding the right solution to legal interpretation see M. Koskenniemi, 'Constitutionalism as Mindset: Reflections on Kantian Themes About International Law and Globalization', (2006) 8 Theoretical Inquiries in Law 9, 21-2.

${ }^{93}$ See M. Koskenniemi, 'Fragmentation of International Law: Difficulties Arising From the Diversification and Expansion of International Law', UN Doc. A/CN.4/L.682, 2006.

${ }^{94}$ Contrast, e.g., on same-sex marriage, Schalk and Kopf v. Austria, Application No. 30141/04, Judgment of 24 June 2010 , with IACtHR, Opinión Consultiva OC-24/17 of 24 November 2017; or on religious attire in public spaces, S.A.S. v. France, Application No. 43835/11, Judgment of 1 July 2014, with HRC, Views concerning communication No. 2747/2016, CCPR/C/ $123 / \mathrm{D} / 2747 / 2016$; besides conflicting rulings on individual issues, regional fragmentation can also lead more foundationally to different conceptions of rights being given prominence in different ways - but see infra Section 5.2, on how Western narratives continue to shape the way in which these different rights are perceived.

${ }^{95}$ Alston's worry that other international bodies besides the General Assembly were recognizing or proclaiming human rights (Alston, supra note 16, at 607) resonates with this position.

${ }^{96}$ As Alston acknowledges by describing process as an indirect means of delineating the proper content of human rights (supra note 90; see also Peters, supra note 6, at 390, noting formal criteria as at most a 'secondary' aspect); Alston also notes the danger of 'manipulation or even circumvention' of the political process (at 621), which presupposes substantive standards to measure what constitutes proper, non-manipulative processes.
} 
for example, one might question the central role of states in determining what counts as a human rights - the old problem of international human rights law 'pulling itself up by its own bootstraps' ${ }^{97}$ Similar tensions can be observed in contemporary debates within human rights theory, which pit so-called moral conceptions and political conceptions of human rights against one another: moral conceptions are said to pay insufficient attention to human rights practice, while political conceptions are said to overemphasize it. ${ }^{98}$

Ultimately, then, the tensions between substance and process confront us with the fact that there are no fixed pre-political criteria for deciding which human rights we have or should have, and which rights claims should, to the contrary, be disregarded because of the inflation they induce. This goes for human rights as an element of political morality as well as human rights as a matter of positive international law - while the latter is typically perceived as less subject to disagreement than moral issues, ${ }^{99}$ both constant contestation in legal practice and critical accounts of the structure of international legal argument demonstrate the limitations of any assumption of determinacy. ${ }^{100}$

The debate about inflation cannot, then, resolve the various open questions surrounding the concept of human rights. Both substantive and procedural criteria have been proposed to stem the proliferation of human rights, and neither seem inherently better suited nor follow naturally from concerns about human rights inflation. As we have seen in the previous section, this indeterminacy pertains not only to the restrictions which are thought to follow from the inflation objection, but also imbues its very scope with an unescapable instability: the question of which modes of human rights proliferation are covered collapses in on itself without a clear answer to which human rights are being protected from devaluation in the first place. This is what I think of as the 'formal emptiness' of the inflation objection.

Given the constitutive paradoxes of human rights law, this formal emptiness is entirely unsurprising, perhaps even banal. I nonetheless think it is important to spell it out explicitly because it helps to lay bare the political work which the inflation objection does by emphasizing the need to 'determine a borderline' of human rights although 'the location of the border is not clear at the outset'. ${ }^{101}$ Differently put: even though the inflation objection does not and cannot contribute any kind of closure to the question of which issues fall within the scope of human rights, it generates a sense of closure by drawing an ostensibly clear boundary between 'real' and 'supposed' human rights. It is this sense of closure and its politics which I would like to dwell on in the following section.

\section{The politics of the inflation objection: A mindset of gatekeeping}

\subsection{Institutional gatekeeping as a response to unruly human rights claims}

If one accepts that the content of human rights is underdetermined and that a decisional element is involved when human rights are (pro)claimed, then the way in which that decision is approached gains significant importance. This aspect has been described in critical legal literature by means of a broad variety of notions, including sensibility, intuition, voice, style, credo, rhetoric,

\footnotetext{
${ }^{97}$ F. Mégret, 'The Apology of Utopia: Some Thoughts on Koskenniemian Themes, with Particular Emphasis on Massively Institutionalized International Human Rights Law', (2013) 27 Temple International and Comparative Law Journal 455, 470.

${ }^{98}$ See S. Besson, 'Human Rights: Ethical, Political ... or Legal? First Steps in a Legal Theory of Human Rights', in D. E. Childress (ed.), The Role of Ethics in International Law (2012); A. Zysset, The ECHR and Human Rights Theory: Reconciling the Moral and Political Conceptions (2017).

${ }^{99}$ E.g., Tasioulas, supra note 21 , at 1176 .

${ }^{100}$ The classic is, of course, Koskenniemi, supra note 42; on human rights see Mégret, supra note 97; M. Koskenniemi, 'The Effect of Rights on Political Culture', The Politics of International Law (2011); J. T. Theilen, European Consensus between Strategy and Principle (2021).

${ }^{101}$ Brems, supra note 41 , at 350.
} 
and performance. ${ }^{102}$ For present purposes, I think it is helpful to think of the inflation objection as a kind of mindset in the sense that, despite its formal emptiness, it nonetheless provides a certain perspective on questions of human rights which influences the way in which arguments are formed and decisions are made. ${ }^{103}$

Allen Buchanan has captured the inflation objection qua mindset quite perfectly by describing 'informal internal constraints' consisting of 'a stable psychological predisposition against the proliferation of rights, but one that is not a reflection of determinate legal principles of constraint'. ${ }^{104} \mathrm{I}$ am interested here in the effects of approaching human rights from within such a mindset; my suggestion is that these effects can be summarized as a form of gatekeeping and hence that they are largely conservative. This entails several different elements, which this and the following subsections will explore.

One effect of an anti-inflation mindset, then, is that it positions human rights claims raised by activists or social movements as potentially dangerous (since they are likely to induce human rights inflation), rather than a potentially necessary or inspirational challenge to currently dominant understandings of human rights. This dynamic is, in a sense, inherent in the idea of preventing inflation: some rights must be protected at the expense of others. My point here, however, is specifically about how the authority to decide on which human rights should be recognized and which should be set aside is distributed - an aspect that is of obvious importance in light of the formal emptiness of the inflation objection discussed above.

At the outset, worries about the inflation of human rights are projected onto various different sites in which they may be enunciated: Upendra Baxi illustratively names institutional, statecentric sites, peoples' struggles, and social movements, as well as intergovernmental and transgovernmental networks. ${ }^{105}$ Dominique Clément, for example, has argued that the inflation of human rights 'takes myriad forms' ranging from legislation and judicial interpretations to the way in which social movements frame their grievances and to shifts in public discourse. ${ }^{106}$

These various sites, however, tend to be perceived somewhat differently from within an antiinflation mindset. Activists or social movements making rights claims are positioned as particularly threatening, for these claims are likely to be made on a vast number of subject-matters - since the elasticity of rights language makes it 'easy to repackage a political movement's agenda in terms of rights' 107 - and with little regard to the proliferation or inflation of human rights. Although the inflation objection does carry some sway within certain 'activist' institutions such as large human rights organizations, ${ }^{108}$ its popularity in less institutionalized contexts is necessarily limited, especially among those who do not deal with human rights professionally but rather use them as a language through which to challenge directly experienced injustices. As Clifford Bob has dryly put it, 'aggrieved groups are unlikely to be deterred by abstract assertions that they should forgo their rights in the interests of the human rights "core"'. 109

So, claims to human rights continue to be made - indeed, one might argue that the conceptual and institutional framework of human rights as a practically relevant and simultaneously

\footnotetext{
${ }^{102}$ The enumeration is from O. Korhonen, 'Innovative International Law Approaches and the European Condition', in J. M. Beneyto and D. Kennedy (eds.), New Approaches To International Law. The European and the American Experiences (2012), 206.

${ }^{103}$ I draw inspiration here, inter alia, from Koskenniemi, 'Constitutionalism as Mindset', at 9, 18; B. A. Ackerly, Universal Human Rights in a World of Difference (2008), 125; both of these are instances of a much more open and self-reflective mindset than the anti-inflation mindset as I consider it here.

${ }^{104}$ Buchanan, supra note 40, at 289.

${ }^{105}$ Baxi, supra note 1 , at $96-7$.

${ }^{106}$ Clément, supra note 21 , at 156.

${ }^{107}$ Nickel, supra note 5, at 96; see also J. P. MacIntyre, 'Community, Law, and the Idiom and Rhetoric of Rights', (1991) 5 Listening: Journal of Religion and Culture 96, 104.

${ }^{108}$ See, e.g., on Human Rights Watch: Whyte, supra note 14, at 77.

${ }^{109}$ C. Bob, 'Introduction: Fighting for New Rights', in C. Bob (ed.), The International Struggle for New Human Rights (2009), 11.
} 
open-ended concept itself prompts the proliferation of human rights claims. ${ }^{110}$ Intervening directly into this discursive process is considered objectionable: it would contravene what Baxi has beautifully captured as the 'human right to interpret all human rights'111 - and even traditionally acknowledged human rights such as the right to freedom of expression point in this direction. ${ }^{112}$ Carl Wellman has summarized the lack of options to prevent the proliferation of rights claims by admitting that 'there is no effective and nonprejudicial way to prevent any public speaker from asserting any right that springs to her mind'. ${ }^{113}$

As a result, Wellman calls for more sustained deliberation, as others also call for 'restraint and moderation'114 - perhaps with echoes of the 'restraint' which neoliberal policies require to prevent economic inflation. The question of how to achieve such restraint, of course, remains. ${ }^{115}$ So Wellman also advocates for a more circumspect approach to legal recognition of claims voiced within political discourse, so as to 'limit legal rights to a manageable number of very important rights. ${ }^{116}$ In a similar vein, Kasey McCall-Smith acknowledges the expression of 'individual preferences and interpretations' of rights as a process which should not be encroached upon directly, but emphasizes the importance of differentiation between rights (or implementation of rights) and of elements of calculation - including regard to both the need for expansion and the danger of inflation - for law and policy makers. ${ }^{117}$

A recurring theme in this context is that rights claims by aggrieved groups are presented, if not as selfish, at least as somewhat suspect since they relate to concrete political interests, whereas state-centric and especially legal institutions benevolently balance competing interests and acknowledge only 'proper' human rights. ${ }^{118}$ In that vein, Hannum suggests that '[p]erhaps the crux of the problem is that many human rights advocates ... confuse their own social agendas with the promotion of internationally recognized human rights'. ${ }^{119}$ International human rights law is thus conceived of as distinct from 'political debate and activism' instead of one of many tools used within, and as a field shaped by such activism. ${ }^{120}$ As Robert Cover has described this view, it is 'the multiplicity of laws, the fecundity of the jurisgenerative principle, that creates the problem to which the court and the state' - and, we might add, the community of states at the international level - 'are the solution'. ${ }^{121}$ Stricter standards for recognition by institutional, state-centric sites of human rights enunciation thus constitute the answer to the unavoidably 'unruly' ${ }^{122}$ proliferation of rights claims.

\footnotetext{
${ }^{110}$ See Beitz, supra note 16 , at 31 ('The evolution of human rights doctrine might be regarded as integral to the larger normative practice').

${ }^{111}$ Baxi, supra note 1 , at 77.

${ }^{112} \mathrm{McC}$ Call-Smith, supra note $30,131$.

${ }^{113}$ Wellman, supra note 16 , at 178 .

${ }^{114}$ E.g., Hannum, supra note 9 (2019), at 157.

${ }^{115}$ See Whyte, supra note 14 , at 176.

${ }^{116}$ Wellman, supra note 16 , at 169.

${ }^{117}$ McCall-Smith, supra note 30 , at 131 .

${ }^{118}$ It is notable, for example, how the self-descriptions given to restraint-based approaches to prevent rights inflation invoke notions of reasonableness, balancing and cool-headedness: they are dubbed a 'radically moderate approach' (Hannum, supra note 9 (2019)), 'enlightened pragmatism' (McCall-Smith, supra note 30), 'differentiated traditionalism' (K. von der Decken and N. Koch, 'Recognition of New Human Rights: Phases, Techniques and the Approach of "Differentiated Traditionalism"', in von Arnauld et al., supra note 38), etc.

${ }^{119}$ Hannum, supra note 9 (2016), at 438 (emphasis added).

${ }^{120}$ Particularly clearly ibid., at 446; see also Hannum, supra note 9 (2019), at 78; contrast, e.g., Dudai, supra note 16 , at 1 $8-19$.

${ }^{121}$ R. M. Cover, 'The Supreme Court 1982 Term. Foreword: Nomos and Narrative', (1983) 97 Harvard Law Review 4, 40.

${ }^{122}$ It is interesting that the term 'unruly' keeps appearing in this context, in different ways and with different connotations; see, e.g., J. Tasioulas, 'The Moral Reality of Human Rights', in T. Pogge (ed.), Freedom from Poverty as a Human Right. Who Owes What to the Very Poor? (2007), 77; A. Orford, 'Embodying Internationalism: The Making of International Lawyers', (1998) 19 Australian Yearbook of International Law 1, 26; see also F. Johns, Non-Legality in International Law. Unruly Law (2013), 9. Ostensible unruliness often also carries a racial component, as demonstrated, e.g., by S. Browne, Dark
} 
The boundary between recognized human rights and mere claims which is reinforced in this way is, again, unstable: any ostensibly recognized right can be challenged by reinterpreting it as a mere claim, for example by arguing that it was wrongly recognized (as many do for certain socioeconomic rights) or that it is insufficiently based on international legal sources to be considered a legal human right (as in debates on whether some 'new' rights merely constitute soft law). ${ }^{123}$ Nonetheless, the anti-inflation mindset offers a distinctly conservative perspective which highlights the importance of restraint, achievable within certain institutions but not within the broad field of 'unruly' rights claims: these are construed not as a call to 'invite new worlds' ${ }^{124}$ or as a 'democratization of interpretation'125 alongside the human right to interpret human rights, but rather as a threat to institutionally recognized human rights. Existing institutions are thus positioned as the gatekeepers of which human rights should be recognized and which should not. By emphasizing gatekeeping by established institutions and de-emphasizing the importance of human rights claims in other sites and by other actors, contestations to the status quo in the shape of the latter are rendered marginal.

\subsection{Which rights are threatening?}

Another effect of the anti-inflation mindset, I would submit, is that it bolsters the status quo by making certain kinds of rights claims appear particularly suspect. Superficially, we might say that these are whichever rights any given author (or treaty-maker, or judge) happens to disagree with: as James Griffin has noted, 'we speak of "proliferation", in a pejorative sense' - or of inflation, perhaps - 'only because we suspect that some of the declared rights are not true rights'. ${ }^{126}$ Because of the formal emptiness of the inflation objection, it could, in theory, be used to defend or vilify any given sets of rights. In practice, however, the inflation objection tends to attach to certain substantive positions despite its formal emptiness. ${ }^{127}$ Based on the literature on human rights inflation surveyed above, we can deduce that those rights claims particularly likely to fall prey to the anti-inflation mindset are by no means aleatory.

It is remarkable, in particular, how consistently socio-economic human rights in the form of welfare rights ${ }^{128}$ have been denied the status of 'real' human rights on the basis of the anti-inflation mindset. Economic and social rights were the primary target of Maurice Cranston's early concerns about human rights inflation based on the distinction between 'real' and 'supposed' human rights. ${ }^{129}$ More recently, Michael Ignatieff argues that rights inflation 'ends up eroding the legitimacy of a defensible core of rights', which he takes to be a 'core of civil and political rights'; ${ }^{130}$ welfare rights, apparently, are indefensible. George Letsas develops a liberal theory of interpretation for the European Convention of Human Rights and concludes from this that the

Matters. On the Surveillance of Blackness (2015). But perhaps to be unruly is also to be willful and assertive; perhaps we might claim unruliness for ourselves? See S. Ahmed, Living a Feminist Life (2017), Ch. 3.

${ }^{123}$ See, e.g., Alston, supra note 16, at 607; Bouwhuis, supra note 51, at 476; Posner, supra note 20, at 94; see also, specifically on sources doctrine and rights expansionism, J. d'Aspremont, 'Expansionism and the Sources of International Human Rights Law', (2016) 46 Israel Yearbook on Human Rights 223; Wuerth, supra note 29, at 320.

${ }^{124}$ Cover, supra note 121 , at 68.

${ }^{125}$ See P. J. Williams, The Alchemy of Race and Rights (1991), 109.

${ }^{126}$ Griffin, supra note 15 , at 93; on the terminology, see supra Section 2.

${ }^{127}$ As Koskenniemi asks, building on David Kennedy: 'Why is it that concepts and structures that are themselves indeterminate nonetheless still end up always on the side of the status quo?'; Koskenniemi, supra note 42, at 606; on the notion of structural bias which he then develops, see infra note 152 .

${ }^{128}$ Jessica Whyte has rightly noted that neoliberalism is not, as the common criticism goes, opposed to economic rights as such: to the contrary, it relies upon economic rights which protect the market freedom of private capital, see Whyte, supra note 14, at 228; see also Slobodian, supra note 14, at 122-3, 134-5; to underline this element, I will mostly speak of welfare rights rather than socio-economic rights, though without needing, for present purposes, to give much more concrete shape to either.

${ }^{129}$ Cranston, supra note 7 , passim.

${ }^{130}$ Ignatieff, supra note 82 , at $89-90$. 
responsibility of the European Court of Human Rights is 'to interpret civil and political rights, not social and economic rights', and that however compelling welfare interests may be, we 'cannot inflate the concept of human rights so much that it covers the whole realm of justice'. ${ }^{131}$ Eric Posner criticizes the 'hypertrophy' of human rights for making the human rights system collapse into 'undifferentiated welfarism'. ${ }^{132}$ Hurst Hannum celebrates some developments of the last decades, especially certain minority rights, as 'welcome advances', but also notes 'rights-inflation criticism' with a particular focus on 'broad economic or political issues' such as poverty, which, on his account, are 'incapable of being rationally debated in the context of rights'. ${ }^{133}$ And even when welfare rights are not targeted as a whole, the anti-inflation mindset tends to focus on broad interpretations of individual welfare rights such as the right to health. ${ }^{134}$

We can learn from this focus of the anti-inflation mindset, because it teaches us which kinds of human rights tend to be perceived as threatening - those which fall outside a (neo)liberal conception of human rights which protects and sustains, or at least does not threaten, the rule of the free market. It is the market, after all, which forms the centre of neoliberal conceptions of freedom and the basis for ostensible beneficial social relations. ${ }^{135}$ But this is not necessarily an exclusively neoliberal position ${ }^{136}$ - for all that neoliberalism is more welcoming than classical laissez-faire liberalism of state intervention, understood as legally constituting and entrenching competition and free markets, either form of liberalism would reject state intervention in the form of welfare rights as described above.

Take Michael Ignatieff's account of a 'defensible core' of civil and political rights which he considers 'strictly necessary to the enjoyment of any life whatever' in that they are 'both an essential motor of economic development in themselves and also a critical guarantee against coercive government schemes and projects'. ${ }^{137}$ As Wendy Brown has summarized it, this involves an argument in favour of understanding 'human rights as the essential precondition for a free-market order and for the market itself as the vehicle of individual social and economic security': in sum, 'as much a brief for capitalism as for human rights'. ${ }^{138}$ Welfare rights would constitute a form of state intervention incompatible with the free-market order; as such, they are rejected as not strictly necessary, and hence viewed as contributing to the inflation of human rights if recognized as such.

As another example, consider Friedrich Hayek's perspective on human rights: He wrote in 1966 that to the important negative rights 'which are merely a complement of the rules protecting individual domains' and to positive rights of participation in the organization of government, 'there have recently been added new positive "social and economic" human rights for which an equal or even higher dignity is claimed'. ${ }^{139}$ We might note in passing the interesting positioning of welfare rights as mere claims despite their recognition in the UDHR which prompted Hayek's criticism. ${ }^{140}$ But more importantly for present purposes, 'these "rights"' (in scare quotes - clearly not 'real'

\footnotetext{
${ }^{131}$ Letsas, supra note 14 , at $129-30$.

${ }^{132}$ Posner, supra note 20, at 94.

${ }^{133}$ Hannum, supra note 9 (2016), at 431-2; my point here, as throughout, is specifically on the way in which the inflation objection is invoked in this context. Hannum combines it with other considerations (e.g., human rights as overly simplistic for responding to structural issues such as poverty) which, to my mind, hold considerably more sway - but need to be disentangled from the inflation objection (see Section 2).

${ }^{134}$ E.g., Tasioulas, supra note 21 , at 1182-6.

${ }^{135}$ Whyte, supra note 14 , at 14 .

${ }^{136}$ See supra, note 14.

${ }^{137}$ Ignatieff, supra note 82 , at 90.

${ }^{138}$ W. Brown, “"The Most We Can Hope For ... ”: Human Rights and the Politics of Fatalism', (2004) 103 South Atlantic Quarterly 451, 456-8.

${ }^{139}$ F. A. Hayek, Law, Legislation and Liberty, vol. 2: The Mirage of Social Justice (2013), 263.

${ }^{140}$ See supra Section 5.1 .
} 
rights!) were fundamentally opposed to Hayek's worldview because they assumed a conception of society going beyond the 'spontaneous order' of 'the cosmos of the market'. ${ }^{141}$

It should come as no surprise at this point that Hayek's defence of negative rights (protecting the market from government interference) and his dislike of welfare rights (based on a social philosophy which would threaten the market) combined in such a way as to raise the inflation objection against the latter: solemnly to proclaim welfare rights, he argued, 'was to play an irresponsible game with the concept of "right" which could result only in destroying the respect for it'. ${ }^{142}$ It is this kind of (neo)liberal approach which continues to underpin much of the anti-inflation mindset, all the more so when the idea of 'inflation' is connected to the narrative that welfare rights are particularly vague, ${ }^{143}$ as well as difficult and costly to implement. ${ }^{144}$ Civil and political rights can thus be constructed as primary, while welfare rights are relegated to Cranston's 'twilight world of utopian aspiration'. ${ }^{145}$

This approach also resonates with the narrative of different 'generations' of human rights (civil and political rights as the first generation, socio-economic and cultural rights as the second generation, and group or solidarity rights as the third generation). ${ }^{146}$ To categorize human rights in this way implies, by virtue of the temporal element of periodization contained in postulating different 'generations', ${ }^{147}$ that socio-economic and group rights are in some sense 'new' and hence more subject to scrutiny ${ }^{148}$ - which provides the space to question whether the 'newer' rights might not devalue the 'older' ones. Here, too, civil and political rights are construed as primary; by universalizing the Western, liberal history of ideas centring the individual, it becomes possible to construct welfare rights or group rights - particularly those associated with non-Western traditions ${ }^{149}$ - as subordinate and potentially threatening in how they differ from civil and political rights.

The shared ground between a (neo)liberal conception of human rights and the anti-inflation mindset also helps to shed light on the way in which some rights claims are read as 'new' even though they belong to what Hayek calls the 'time-honoured' civil and political rights. ${ }^{150}$ For all the ambiguities discussed above, there is a sense that certain understandings of human rights - notably, Western (neo)liberal approaches to them - are currently dominant. ${ }^{151}$ Accordingly, although abstract human rights principles can be and are interpreted in many different ways, their common

\footnotetext{
${ }^{141}$ Hayek, supra note 139, at 264; for further context (and a wonderful account of the emergence of the neoliberal approach to human rights more generally) see Whyte, supra note 14 , at 75-6.

${ }^{142}$ Hayek, ibid., at 265; this is also another case of an eerie linkage between social and economic terms (supra, Section 2.): state welfare leads, on a neoliberal account, not only an inflation of human rights but to economic inflation, too.

${ }^{143}$ E.g., Buchanan, supra note 40, at 286-7.

${ }^{144}$ See critically B. Authers and H. Charlesworth, 'The Crisis and the Quotidian in International Human Rights Law', (2013) 44 Netherlands Yearbook of International Law 19, 36; on the connection between costs and inflation of rights see also Quintavalla and Heine, supra note 81; McCall-Smith, supra note 30.

${ }^{145}$ Supra, note 8 .

${ }^{146}$ Originating in K. Vasek, 'A 30-Year Struggle: The Sustained Efforts to Give Force of Law to the Universal Declaration of Human Rights', (1977) 10 Unesco Courier 29.

${ }^{147}$ D. J. Whelan, Indivisible Human Rights. A History (2010), 211.

${ }^{148}$ As noted by R. Cruft et al., 'The Philosophical Foundations of Human Rights: An Overview', in R. Cruft, et al. (eds.), Philosophical Foundations of Human Rights (2015), 23; see, e.g., S. Domaradzki et al., 'Karel Vasak's Generations of Rights and the Contemporary Human Rights Discourse', (2019) 20 Human Rights Review 423, 425. For criticism ('historically inaccurate, analytically unhelpful, and conceptually misguided') see P. Macklem, 'Human rights in international law: three generations or one?', (2015) 3 London Review of International Law 61.

${ }^{149}$ As expressed, e.g., in the African Charter on Human and Peoples' Rights (Banjul Charter).

${ }^{150}$ Hayek, supra note 139, at 263.

${ }^{151}$ See supra note 13, and specifically on neoliberalism, e.g., Whyte, supra note 14, at 3-4; P. Cheah, Inhuman Conditions. On Cosmopolitanism and Human Rights (2006), 145; P. O'Connell, 'On Reconciling Irreconcilables: Neo-liberal Globalisation and Human Rights', (2007) 7 Human Rights Law Review 483, 486-8.
} 
interpretation in fact, within current institutions, reflects certain structural biases. ${ }^{152}$ Those interpretations which run counter to those biases will, broadly speaking, be perceived as 'new' and subjected to stricter scrutiny on the basis of the anti-inflation mindset. 'New' rights in this sense - and the lawyers who advocate for them - are thus 'constituted as marginal in order to contain the threats they pose'. ${ }^{153}$

I would argue that this is the case, for example, with minority rights. To a certain extent, these are (by now) accepted as a matter of course, e.g., with regard to decriminalization of same-sex acts or relatively superficial anti-discrimination measures; ${ }^{154}$ such forms of protection may even be considered integral to the very idea of human rights. ${ }^{155}$ This is in line with what Nat Raha calls the neoliberal incorporation of difference, ${ }^{156}$ since certain forms of minority protection can easily be commodified and made to serve neoliberal ends. By contrast, more far-reaching human rights for marginalized and oppressed groups - disability rights beyond 'reasonable accommodation', ${ }^{157}$ for example, or trans rights that subvert gender norms rather than reinforcing them ${ }^{158}$ - challenge the structural bias of human rights law and are hence more likely to be perceived as 'new' and liable to induce inflation. ${ }^{159}$

Ultimately, then, the more a human rights claim is geared at far-reaching social transformation, the more threatening it seems from within the anti-inflation mindset. This dynamic is exemplified in the case of welfare rights which threaten the (neo)liberal hegemony, but we can also see it in action when other human rights claims surpass what can be accommodated within currently dominant understandings of human rights, and it constitutes a further way of bolstering the status quo.

\subsection{Positioning human rights as superior to other languages of resistance}

A further effect of an anti-inflation mindset based on gatekeeping is that it has consequences not only for the way we think about certain human rights claims, but also about the concept of human rights as a whole. After all, the anti-inflation mindset involves drawing a boundary around human rights vis-à-vis other normative concepts. ${ }^{160}$ It has been argued, for example, that while welfare rights might hold moral ground, they should not be regarded as 'a problem about the universal rights of all men' (much less of all women or people of other genders, one surmises) but rather as 'a problem of socialization or democratization'. ${ }^{161}$ Many authors emphasize the distinctiveness of human rights in a similar way: they have been deemed particularly 'distinctive and important', ${ }^{162}$ aiming to 'protect only the most significant human interests', ${ }^{163}$ as possessing 'distinctive moral

\footnotetext{
${ }^{152}$ See generally on the notion of structural bias Koskenniemi, supra note 42, at 606-7; P. Kotiaho, 'A Return to Koskenniemi, or the Disconcerting Co-optation of Rupture', (2012) 13 German Law Journal 483, 488.

${ }^{153}$ Orford, supra note 122 , at 26.

${ }^{154}$ See, for example, Dudgeon v. the United Kingdom, Application No. 7525/76, Judgment of 22 October 1981; S.L. v. Austria, Application No. 45330/99, Judgment of 9 January 2003.

${ }^{155}$ E.g., Nussbaum, supra note 57 , at 77.

${ }^{156}$ N. Raha, "Queer Marxism and the Task of Contemporary Queer Social Critique", academia, available at www.academia. edu/9220681/Queer_Marxism_and_the_task_of_contemporary_queer_social_critique.

${ }^{157}$ See critically on 'reasonable accommodation': P. Vargiu, “Am I a person?”, available at www.paolovargiu.com/blog/am-ia-person-part-i, especially parts I and V.

${ }^{158}$ On the difficulties involved in this see G. Baars, 'Queer Cases Unmake Gendered Law, Or, Fucking Law's Gendering Function', (2019) 45 Australian Feminist Law Journal 15; J. T. Theilen, 'Subversion Subverted: Developments in German Civil Status Law on the Recognition of Intersex and Non-binary Persons', in E. Brems, et al. (eds.), Protecting Trans ${ }^{\star}$ Rights in the Age of Gender Self-determination (2020).

${ }^{159}$ In both these example cases much energy is therefore spent on strategically presenting disability rights and trans rights as not new; see supra notes 61,62 .

${ }^{160}$ See Tasioulas, supra note 21 , at 1173 , arguing that human rights law has 'transgressed its proper bounds'.

${ }^{161}$ Cranston, supra note 7 , at 173 (emphases in original).

${ }^{162}$ Wellman, supra note 16 , at 128 .

${ }^{163}$ Posner, supra note 20 , at $91-2$.
} 
force' compared to 'the whole realm of justice', ${ }^{164}$ and as of 'distinctive significance' while not exhausting 'the whole field of moral concern' 165 and distinct from 'all socially desirable progress' ${ }^{166}$ Some authors also distinguish, to similar effect, between human rights and 'mere' rights tout court: 'there is a grave danger that if we speak glibly about human rights, we may lose sight of the reality that some rights are more basic than others'. ${ }^{167}$

In the context of an anti-inflation mindset, statements such as these not only position human rights as distinct from social justice (or socialization, morality, rights tout court, and so on); the notion of human rights is also constructed as hierarchically superior to other normative frames. As Dominique Clément has argued, the insistence that framing various grievances as violations of human rights undermines the moral legitimacy of human rights is based on the presumption that human rights have a greater moral claim than social justice'. ${ }^{168}$

In this way, even as other normative concepts are pointed to as a kind of safety net for those claims which don't make the cut as human rights, they are constructed as conceptually subordinate to human rights. The derogatory implications of deeming some human rights claims 'supposed', 'illusory', 'fake ${ }^{169}$ or 'wannabe' ${ }^{170}$ also resonates with and further contributes to this form of hierarchization. One effect of a mindset which foregrounds the gatekeeping of human rights in this way, then, is to create a discursive culture in which vocabularies by means of which to contest the status quo - what Balakrishnan Rajagopal calls 'language[s] of resistance ${ }^{171}$ - other than human rights, are made to seem increasingly marginal.

Combined with the previous parts of my argument, this leads me to conclude that the antiinflation mindset has several, mutually reinforcing effects. It serves, first, to reinforce currently dominant, (neo)liberal understandings of human rights, both by positioning existing institutions as the gatekeepers of 'proper' understandings of human rights and by putting into question any human rights claims aimed at far-reaching social transformation. This cannot prevent such claims from being articulated in different languages of resistance, but the anti-inflation mindset does, second, position normative frames other than human rights as hierarchically inferior to human rights themselves, thus creating an additional barrier to challenging those aspects of reality including, e.g., property rights and a free-market order ${ }^{172}$ - which are already deemed part of human rights. The double-bind this creates for challenges to the status quo is what makes the anti-inflation mindset, to my mind, a form of gatekeeping with deeply conservative political effects.

\section{Outlook: The merits of wonder}

I have argued that the inflation objection, despite being characterized by a formal emptiness, involves a mind-set of gatekeeping which benefits the currently dominant (neo)liberal understanding of human rights and makes challenges to the status quo, whether in the form of human rights or other languages of resistance, more difficult. As I noted at the outset, this could also be described as giving too much weight to the abstract 'value' of human rights rather than the specific

\footnotetext{
${ }^{164}$ Letsas, supra note 14 , at 129.

${ }^{165}$ Tasioulas, supra note 21 , at 1191-2.

${ }^{166}$ Hannum, supra note 9 (2016), at 438.

${ }^{167}$ G. Sjoberg et al., 'A Sociology of Human Rights', (2001) 48 Social Problems 11, 43; see also M. A. Glendon, Rights Talk.

The Impoverishment of Political Discourse (1991), 16; Marks, supra note 67, at 128; Peters, supra note 6, at 387.

${ }^{168}$ Clément, supra note 21 , at 159.

${ }^{169}$ See supra note 92.

${ }^{170}$ Hannum, supra note 9 (2019), at 61.

${ }^{171}$ Rajagopal, supra note 13 , at 232.

${ }^{172}$ See supra note 137.
} 
privileges, power constellations, and struggles which underlie them. ${ }^{173}$ In this way, the 'value' of (currently dominant understandings of) human rights is positioned as primary, while other claims and other normative frames are constructed as subordinate - echoing the classic boundarydrawing which places issues or people inside or outside the law. ${ }^{174}$

However, these hierarchically constructed relations are not static but rather unsettled and unstable. ${ }^{175}$ Sara Ahmed has argued that 'the integrity of law as a system is always under threat by its "others", by that (and those) which it seeks to exclude and repress'; ${ }^{176}$ we might consider the inflation objection one way in which the area of human rights law, specifically, responds to such threats by establishing a mindset of gatekeeping in response to 'unruly' rights claims. But this can never be set in stone. Ahmed continues: 'what the law excludes through the process of policing its boundaries' - or gatekeeping, as I have been calling it - 'can be rearticulated as internal to law, to law's self-definition as law'. ${ }^{177}$

In a sense, this constant process of rearticulation and redefinition could even be considered entirely unremarkable, part and parcel of constant discursive shifts in the morality, politics, and law of human rights. ${ }^{178}$ Claims to new (interpretations of) human rights, as noted above, ${ }^{179}$ will continue to be made so long as the vocabulary of human rights forms 'an undeniably empirical element ${ }^{\text {'180 }}$ of the world, so long as we 'cannot not want' human rights. ${ }^{181}$ Experience shows that some of these claims will be recognized, often after years and decades of struggle and activism. ${ }^{182}$ These complex and multidirectional processes take place within a great many intersecting power structures and involve both strategic and principled decisions by a vast number of actors of all kinds. I am not, of course, claiming some kind of directly tangible and monocausal effect of the inflation objection within these processes. And yet, if we accept that it involves a mindset of gatekeeping which has the potential to shape how we think about human rights and how we approach decisions - if we accept, in other words, that it forms part of the 'underlying world of beliefs that controls our institutional practices' 183 - then we cannot simply set it aside as a harmless theoretical curiosity, either.

Opposing the anti-inflation mindset for the conservative effects it has is not to say that any extension of human rights, much less human rights law, is to be welcomed. ${ }^{184}$ As the above discussion of (neo)liberal human rights exemplifies, there is nothing inherently emancipatory about human rights, including 'new' rights claims - no more than international law in general do they

\footnotetext{
${ }^{173}$ For a particularly stark invisibilization of these struggles, see Hannum, supra note 9 (2016), at 438, arguing that greater equality is likely to develop 'almost inevitably'.

${ }^{174}$ D. A. Gonzalez-Salzberg, 'An Improved Protection for the (Mentally Ill) Trans Parent: A Queer Reading of AP, Garçon and Nicot v France', (2018) 81 Modern Law Review 526, 529; from a different perspective see Johns, supra note 122, at 8; see also supra notes 41,42 .

${ }^{175}$ See supra Section 2.

${ }^{176}$ S. Ahmed, 'Deconstruction and Law's Other: Towards a Feminist Theory of Embodied Legal Rights', (1995) 4 Social and Legal Studies 55.

${ }^{177}$ Ibid.

${ }^{178}$ See generally, e.g., J. Habermas, Between Facts and Norms (translated by W. Rehg) (1996); this is generally acknowledged even by those who invoke the inflation objection, see, e.g., Hannum, supra note 9 (2016), at 412.

${ }^{179}$ Supra Section 5.1.

${ }^{180}$ Supra note 28.

${ }^{181}$ R. Kapur, 'Human Rights in the 21st Century: Take a Walk on the Dark Side', (2006) 28 Sydney Law Review 665, 682, echoing Spivak. Incidentally, this brings us back full circle to the deconstructive stance mentioned above: 'Deconstruction, if one wants a formula, is, among other things, a persistent critique of what one cannot not want'; G. C. Spivak, 'Bonding in Difference, interview with Alfred Arteaga', in D. Landry and G. MacLean (eds.), The Spivak Reader (1996), 28.

${ }^{182}$ Although there is, of course, a pattern to which (kind of) rights are recognized, and in what way: see illustratively C. Clark, 'Of What Use is a Deradicalized Human Right to Water?', (2017) 17 Human Rights Law Review 231. Once a right is recognized in certain fora the inflation objection may still be relevant regarding its interpretation: see supra Section 3.

${ }^{183}$ See supra note 37.

${ }^{184}$ See supra Section 2, on the distinction between the inflation objection and other objections to human rights proliferation.
} 
contain an 'ideal of the good society'. ${ }^{185}$ Upendra Baxi's distinction between the politics for human rights (which 'combats as overproduction the regimes of protection of the rights of global capital, while celebrating the newly emergent rights of peoples') and the politics of human rights (which does the opposite) captures this in particularly vivid form. ${ }^{186}$

As we navigate these ambiguities, perhaps we can learn from the way in which the anti-inflation mindset aims to shut down social transformation by inverting its approach into its opposite. ${ }^{187}$ It is notable, in particular, how often the inflation objection is connected to language deriding utopian aspirations. I have already referred repeatedly to Cranston's distinction between 'morally compelling' human rights and 'the twilight world of utopian aspiration'. ${ }^{188}$ Much more recently, John Tasioulas has mirrored this language by proposing that the best way to assuage 'anxiety about human rights inflation' would be to reject broad accounts of human rights law as 'a blueprint for utopia' - he even dubs the emphasis on the 'distinctive significance' of human rights an 'antiutopian insight'. ${ }^{189}$

The anti-utopian bent of the inflation objection should not come as a surprise; neoliberalism often seeks to essentialize itself by undercutting the ability to think or feel utopian alternatives. ${ }^{190}$ Focusing on precisely those utopian alternatives, then, might be a remedy to the anti-inflation mindset. While utopianism carries its own dangers - continuing its history of realizing orientalist Western utopias at the expense of populations in the Global South, for example ${ }^{191}-$ it can also be associated with imagination, self-reflexion, and critique. ${ }^{192}$ In this counter-hegemonic form, utopianism aims to make 'the actual world seem strange' ${ }^{193}$ and shatter the 'taken-for-granted nature of the present'. 194

In keeping with the utopian commitment, we might seek to cultivate a mindset of wonder as a way of unsettling the status quo. ${ }^{195}$ To wonder, as Sara Ahmed has put it, is 'to remember the forgetting and to see the repetition of form as the "taking form" of the familiar'; ${ }^{196}$ it is thus at the heart of the utopian enterprise which seeks to make the world as it is 'seem strange'. From this perspective, when claims that are far removed from currently dominant understandings of human rights seem outlandish, we might take this as an occasion not to dismiss them, but to ask which structures and assumptions make us consider them outlandish. ${ }^{197}$ Why are things as they are? Why should they not be different?

As an example, not so as to build a substantive argument for a particular claim but merely to sketch the shift in mindset which I am envisioning, consider the human right of access to law as

\footnotetext{
${ }^{185}$ Koskenniemi, supra note 42 , at 613 .

${ }^{186}$ Baxi, supra note 1 , at 112 .

${ }^{187}$ See also supra note 122 .

${ }^{188}$ Supra note 8 .

${ }^{189}$ Tasioulas, supra note 21 , at $1181,1191-2$.

${ }^{190}$ See J. T. Theilen et al., 'Towards Utopia - Rethinking International Law', (2017) 60 German Yearbook of International Law 315, 317.

${ }^{191}$ See M. d. M. Castro Varela and N. Dhawan, Postkoloniale Theorie. Eine kritische Einführung (2020), 353.

${ }^{192}$ E.g., E. Bloch, Das Prinzip Hoffnung (2016), 724; in the context of international law see M. Koskenniemi, 'Projects of World Community', in A. Cassese (ed.), Realizing Utopia. The Future of International Law (2012); Theilen et al., supra note 190 , at 328.

${ }^{193}$ P. Ricoeur, Lectures on Ideology and Utopia (1986), 299.

${ }^{194}$ R. Levitas, 'The Imaginary Reconstitution of Society: Utopia as Method', in T. Moylan and R. Baccolini (eds.), Utopia Method Vision. The Use Value of Social Dreaming (2007), 57.

${ }^{195}$ See Bloch, supra note 192, at 557; in the context of philosophy, see P. Allott, Eutopia. New Philosophy and New Law for a Troubled World (2016), 182; and, more broadly on the utopian tradition in relation to international law, J. T. Theilen, 'Of Wonder and Changing the World: Philip Allott's Legal Utopianism’, (2017) 60 German Yearbook of International Law 337, $346-7$.

${ }^{196}$ S. Ahmed, Queer Phenomenology (2007), 82-3.

${ }^{197}$ See S. Ahmed, The Promise of Happiness (2010), 165.
} 
proposed by Simon Rice. ${ }^{198}$ Going beyond the relatively well-established right to legal aid, the right of access to law is said to relate also to individuals' engagement with state law outside of the trial context, given the pervasive presence of law in everyday life. ${ }^{199}$ Based on a mindset of gatekeeping and concerns about inflation, responses to such a proposal might go something like this: it would be 'absurd' to suggest that one could know the content of 'all law'; ${ }^{200}$ the resources to enable knowledge of and access to the law by everyone are unfathomable and better spent on other matters; to recognize a human right of access to law would make human rights lose all contours (as someone asked at a recent workshop: would the right of access to law require public transportation for rural populations so as to reach lawyers and courts in the next bigger city?); it would therefore endanger the enterprise of human rights as a whole ${ }^{201}$ and should not be recognized outside of the narrow ambits of a right to legal aid.

A mindset of wonder, by contrast, would pick up on the ostensible absurdity of the proposal not as a way of closing down, but as a way of opening up political contestation by asking why the right of access to law seems absurd and who profits from framing it as such. Which material and discursive structures separate those who have access to law from those who don't? ${ }^{202}$ Why should it not be possible to provide, for example, broader education on legal (and other) matters and meaningful material support to disenfranchised or rural populations (including, yes, some form of public transportation)? To wonder at how things are does not necessarily lead to any particular stance on the issue in substance 203 - for example, one might be sceptical of the right of access to law for the way it centres law itself, rather than questioning its omnipresence in our lives and the relations of domination in can conceal. ${ }^{204}$ But to wonder in this way does invite us to imagine how things could be otherwise, and thus to open up avenues for debating transformative political action rather than giving a privileged place to the status quo. ${ }^{205}$

In brief: the 'outside' of human rights, from within a mindset of wonder, would not be perceived as subordinate or threatening; rather, it becomes an essential element on the basis of which to (self-)critically assess the status quo. As Baxi has put it, those 'who feel excluded from the contemporary human rights regime' - he cites those advocating for a human right to sexual orientation as an example - 'may, with considerable justification, maintain that the tasks of human rights enunciation have just barely begun'. ${ }^{206}$ Kathryn McNeilly lays an even stronger focus on this element in her futural conception of human rights which entails 'approaching rights politics as not about claiming, applying or enforcing already existing articulations of human rights, but about

\footnotetext{
${ }^{198}$ Another commonly cited example for an 'inflationary' right is the right to periodic holidays with pay (part of the right to rest and leisure, along with the reasonable limitation of working hours, in Art. 24 UDHR); for criticism of this right as too trivial for a human right see, e.g., Cranston, supra note 7, at 171-2; Nickel, supra note 5, at 37, 96; Wellman, supra note 16, at 2, 177; Griffin, supra note 15, at 5, 209; Posner, supra note 20, at 92. I suppose from the comfortable vantage point of a tenured professor it might seem so, but to trivialize workers' rights in such a way does very clearly showcase the way in which the mindset of gatekeeping privileges some perspectives at the expense of others. For a counterpoint see D. Luban, 'Human Rights Pragmatism and Human Dignity', in Cruft et al., supra note 148, at 276.

${ }^{199}$ S. Rice, 'Bentham Redux. Examining a Right of Access to Law', in von Arnauld et al., supra note 38, at 541-2.

${ }^{200}$ Ibid., at 545, citing L. Alexander, 'Ignorance as a Legal Excuse', in R. Peels (ed.), Perspectives on Ignorance from Moral and Social Philosophy (2017), 208. Absurdity recurs: 'One criticism of human rights to goods and services (subsistence, health, education) claims that such rights are absurdly demanding' (Cruft et al., supra note 148, at 24); 'The fact ... that some environmentalists can seriously assert that trees and ecosystems have moral rights ... seems to many a reductio ad absurdum of the very idea of moral rights' (Wellman, supra note 16, at 177) (emphases added).

${ }^{201}$ See the concerns about inflation cited (but disregarded) by Rice, ibid., at 543 .

${ }^{202}$ See, e.g., Harvey, supra note 19 , at 51-2.

${ }^{203}$ In a similar way, perhaps, to the way in which critique does not define a precise meaning of emancipation: see Marks, supra note 35 , at 137.

${ }^{204}$ M. Koskenniemi, 'Epilogue. To Enable and Enchant - on the Power of Law', in W. Werner, et al. (eds.), The Law of International Lawyers. Reading Martti Koskenniemi (2017), 393.

${ }^{205}$ See Theilen, supra note 195 , at 348.

${ }^{206}$ Baxi, supra note 1, at 112; see also P. Alston, 'Making Space for New Human Rights: The Case of the Right to Development', (1988) 1 Harvard Human Rights Yearbook 3, 6-7.
} 
challenging and debating human rights based on the inevitable alterity and exclusion of current rights concepts and ideas' ${ }^{207}$ Excess, from this perspective, does not threaten human rights. To the contrary, it is both unavoidable and welcome; human rights can be thought of as 'driven by excess', 'permanently unsettled and unfinished'. ${ }^{208}$

An anti-inflation mindset is by no means necessary, then, nor 'the liberal conception of rights as a minimum standard' which it seeks to entrench. ${ }^{209}$ In the current juncture of (neo)liberal hegemony, the idea of human rights as minimum standards to be protected from devaluation 'always attempts to limit or deny the transformative power of human rights', but it 'never succeeds in extinguishing it ${ }^{210}$ - as the continued anxieties about human rights inflation show. We can retain a mindset of wonder. We can retain our moral outrage. We can retain our willingness to be shocked by the status quo.

${ }^{207} \mathrm{McNeilly,} \mathrm{supra} \mathrm{note} \mathrm{2,} \mathrm{at} 26$ (emphasis added).

${ }^{208}$ Ibid., at $15-16$.

${ }^{209}$ M. Lattimer, 'Two Concepts of Human Rights', (2018) 40 Human Rights Quarterly 406, 419.

${ }^{210}$ Ibid. 